Kalampalikis, N., Haas, V. (2008).

More than a theory: a new map of social thought.

Journal for the Theory of Social Behaviour, 38(4), 449-459.

\title{
MORE THAN A THEORY: A NEW MAP OF SOCIAL THOUGHT
}

Nikos KALAMPALIKIS \& Valérie HAAS ${ }^{*}$

In this article we revisit two different temporal phases related to the main publication of Serge Moscovici's book $L a$ Psychanalyse, son image et son public together with two key promissing notions of the theory, cognitive polyphasia and anchoring. The first phase, initiated by the durkheimian cercle, will give us the occasion to retrieve the traces of the fascinating intellectual debate about collective psychology that was involved in producing "frontier" propositions and renewing their perspectives in today's light, namely throught cognitive polyphasia. The second phase, more recent, inspired by classical and modern research into the social representation's field, will serve us as a basis for a new hypothesis about anchoring. We will attempt to suggest that traditional familiarization allocated to anchoring can also work in the opposite sense, transmitting and guaranteeing the non-familiar, establishing strangeness. Finally, we are arguing that social representations are more than a simple theory, just as the symbol is always more than what it symbolizes.

Key words : social representations, cognitive polyphasia, anchoring, familiarization, strangeness

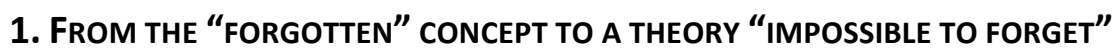

We find ourselves faced with a paradox. From the very first edition of La Psychanalyse to the most recent publications devoted to social representations, we never cease to repeat Serge Moscovici's reprise of a Durkheimian concept fallen into disuse a good half-century ago. At the same time, today, half a century after the publication of the major scholarly work, we are attempting to rediscover new paths to explore this concept. Thus, from the "forgotten" concept we are now finding ourselves facing a theory "impossible to forget".

The paradox becomes disconcerting when we contemplate the large amount of work produced in the meantime that has been directly inspired by La Psychanalyse, henceforth a classic. Thus, how to return to the past, how to claim a new look at this book, when the settings of the past, the social frameworks of the past memories, in the Halbwachs's (1925) sense - space, time and language - have largely been coconstructed as much by La Psychanalyse as by the entire body of research that since it has inspired? Without mentioning the themes taken from the past, the research and texts, as well as numerous authors - all this has left their marks on our work and has inspired us. Different paths, not at all linear, have guided us through a labyrinth and directed us to read, interpret and think such and such facet of this theory. How can we not adopt a "presentist" attitude involving re-reading this publication in the light of effects it has had, the generations of researchers it has produced, the corpuses of studies it made possible and the interpretive power it holds?

We have here a very delicate task consisting of returning to a past event in order to reread it in today's light. This one event is a crucial publication, forty-seven years after its first original edition and thirty-two years after the reworded edition. The distressing paradox, raised in the beginning, becomes symbolic because the date of the published translation, celebrated in this special issue coincides, and commemorates, no doubt 
unintentionally, one hundred and ten years since the publication of Émile Durkheim's prophetic article "Représentations individuelles et représentations collectives" $(1898)^{i}$ (Individual and collective representations).

Here we are now, facing a double mystery. On the one hand, the mystery of the forgotten, yet so powerful and promising concept, and, on the other hand, the mystery of the incredible longevity of what has become the theory of social representations. Let us leave the mysteries for the historians of sciences and rather attempt to devote ourselves to the two contrasting temporal directions that are a filigree of these findings. They will serve, each in its own way, as clues to assist us in re-visiting two key notions of the theory, cognitive polyphasia and anchoring.

Our main argument in this article maintains that if social representations approach encountered such a development within and outside the discipline, it has happened because it surpassed, and went beyond its first theoretical confines. By this we mean that it has gone beyond a "simple" theory, or "additional" theory. Indeed, the past half century has amply proven that it is more than a theory. We could search for reasons of this surplus by exploring the power of ideas advanced in 1961. Or, we could try, in terms of Thomas Kuhn's (1970), to use a new epistemological vocabulary to describe it. We would probably be right in doing so, but this quest would not be complete without also searching for reasons, conditions and debates that this "forgotten" concept has produced since its appearance at the end of the $19^{\text {th }}$ century. A necessary flashback that would enable us to comprehend that the 1961 "theory" was in certain ways destined to become what it is for many of us today, a new map of social thought.

\section{A NEW TERRITORY OF THOUGHT: THE COLLECTIVE PSYCHOLOGY}

The formulation of collective psychology was one of the most productive periods in the history of social sciences, as it sought to capture the evolution and force of social thought. It was created gradually from the start of the last century - and, to a large extent, with, around and against Durkheimian theses. Notwithstanding its institutional acceptance, it was the product of academic circumstances, as well as of social and political (cf. Halbwachs, 1999; Karsenti, 1995) conditions. It bears within itself the foundations of a debate that we are still pursuing today, aiming to capture the polymorphic nature of social knowledge. With some distance, and following various objectives, several authors have concentrated on the genesis of this phase, the conditions of its development, its vitality or even its protagonists (Fournier, 2007). It is of interest to us here that Serge Moscovici's oeuvre has actively participated for a half century, and is still participating, in the renewal of these perspectives.

This reconciliation is far from strange when we consider the project promoted by certain representatives of this movement, Maurice Halbwachs, Marcel Mauss, Lucien Lévy-Bruhl, to name a few, who were no more than defenders of a new realm of thought: collective psychology. The strangeness takes on kinship ties once we realize that this new territory has been brilliantly designed, some decades later, as a "psychosocial point of view" ("regard psychosocial") by one of the founders of European social psychology. We may also consider, in the light of the present, the relevance of Durkheim's concept of "collective representations" for the theory of social representations, which has become, since 1961, one of the most productive and 
strongest psychosocial theories in the world. This new disciplinary geography from the beginning of the last century had this distinctiveness, productivity, the desire to operate a sort of intellectual acrobatics between historical, sociological and psychological (Revel, 1996; Bruner, 1996) disciplines. This was a true antithesis to a closed and inhospitable way of thinking; or, to change the vocabulary, it was a science open to the world and it was characterized by a desire to be open, one could even say hospitable, whether this occurred through the incorporation of various current theories or because of its humanist and political design. The stakes were important and their progress (conceptual, notional, and theoretical) called upon interdisciplinary dialogue. A range of mental tools was emerging through updated publications and this has created the foundations on which social sciences are based today. Take, for example, the timely reconciliation between history and psychology, beautifully illustrated by Parot (2000), taken from Meyerson's symbolic case that more or less worked towards a historical psychology of collective representations:

"Efforts to reject any fixist conception of social and mental phenomena were thus combined. This is precisely when the important concept of mentality was developed by the new historians to call sociologists and psychologists to work with them. Against purely descriptive history--that positivist history that considered the historical and, above all, political facts to be at the heart of the discipline--the historians of the Annales promoted the long-term history of civilization and collective imagination. History had to take an interest in the structure of thought as a set of economic, social, political, and religious characteristics of the spirit of the times, the Zeitgeist, which Lucien Febvre called in 1942 in his Rabelais the "outillage mental" (mental tools). To study the evolution of these mental tools and Durkheimian collective representations, it was necessary to create a "historical psychology" that would describe the complex relations between these collective and individual representations and their impact on psychological functions such as perception and memory". (Parot, 2000, p. 114).

Here is, most likely, a first labour path for us in the years to come taken from the initial thought processes of $L a$ Psychanalyse: to retrieve the traces of the fascinating intellectual debate that was involved in producing "frontier" propositions and renewing their perspectives in today's light. Is it a simple historical curiosity? On the contrary, this is a vital necessity for those who wish to retrace the evolution of social thinking in order to locate the numerous common denominators of a direct epistemological relation. One of them could find a fruitful illustration through what has been declared as a hypothesis in the initial publication of La Psychanalyse, cognitive polyphasia.

\section{COGNITIVE POLYPHASIA}

We know that the theoretical approach of social representations has focused, since its beginnings, on the study of natural thought and its reasoning regarding scientific theories rather than on the vast domain that covers the expansion of knowledge, scientific vulgarization and the didactics of sciences, among others. An important collection of research has been developed around the notion of practical knowledge by excellence, common sense. The latter is conceived as a set of daily theories with their own epistemology, their symbolic efficacy, and their temporal, historical and 
mnemonic declarations: on knowledge as naive as it was true. As a filigree of this work, the other knowledge was always projected; the scientific, expert, objective; shortly, providing truth.

However, these distinctions have evoked a lineage of research in psychology, sociology, anthropology and history that converge around this same concern. Let us consider the work of Lucien Lévy-Bruhl (1949), covering primitive mentality and participation; the work of Jean Piaget (1926) regarding the various reasoning methods of children; or even Claude Lévi-Strauss's (1947) reflective thinking on the archaic illusion. Considering what different authors and their enquiries said about the dynamics of social knowledge, we could summarize that as follows: no form of society, no matter how modern, has the prerogative of using only one form of rationality, mentality, knowledge (Haas, 2006).

Here is one point that, naturally, did not escape Moscovici's original work when he proposed the hypothesis of cognitive polyphasia, that is to say, this polymorphic state of consciousness (language, thinking) that social subjects utilize in their interactions. We are barely beginning to work on this hypothesis itself (cf. also Duveen, 2000; Haas, 2006; Kalampalikis, 2007; Marková, 2003; Moscovici, 2000; Wagner and Hayes, 2005), and to pay closer attention to the effects of knowledge transformation. Thus, as is written by Jovchelovitch (2006), this concept allows a new reading of the knowledge problem: knowing is an activity that must be conceived in terms of its relation with the context from where its logic and rationality emerges. For the time being we can contend that with all social subjects, no matter how knowledgeable they are, there are as many relations between social subjects and knowledge as there are their relations towards the world. The representation of shared knowledge is determined by the individuals using schemata of social thinking; these are integrated into their value systems depending on their history, previous experiences, belongingness and social context.

It is in this perception, we believe, that the hypothesis of cognitive polyphasia produced the polymorphic nature of social thought, "the dynamic co-existence of modalities of individual knowledge, corresponding to concrete relations between man and his environment" (Moscovici 1961, p. 402). This position allows us to unite with the initial aim of this theory, the study of the dynamics of social thought in synchrony with its emergence, transformation and conditions of circulation. After all, Maurice Halbwachs wrote, staring in 1938, "social thought may simply be just a mixture that operates by necessity between two kinds of logic, affective and objective, and this is why it is essentially illogical. (...) But, are we representing different regions or environments, in one society, in which there are many relations, because a large amount of individuals continuously circulate and pass between each other. Thus, we can now comprehend that such logical and illogical thought processes, based on positive reasoning or emotional data, could collide, conflict and contradict, but also get organized together and unify, and that we could specifically make available, to a belief or a sentiment, all dialectic resources that are offered by the various groups to which we find ourselves attached" (1938, p. 367, our translation).

In its initial formulation, cognitive polyphasia is closely linked to the multiple relations between humans and their environment, to the multiple facets of our knowledge of the world, and to our multiplicity of being in this same world. In other words, 
polyphasia is linked to the dynamics of social thought and to its entry into moving settings. Along the same lines, we belong to multiple and various social groups, we play numerous roles in the social scene of daily life; we are part of the mosaic of our identity matrix, the variety of our intentional states; and we partially share our representations (Kalampalikis \& Moscovici, 2005): society's voice is polysemous. The language of social representations carries with it the markings of this polysemy.

We should be aware of falling into the trap, which has too often tempted social psychologists, of contemplating this wealth from a strictly cognitive point of view, via the error notion, or of considering solely the mental balance of incompatible cognitions. We must remind that from its first definitions, social representation has appeared as a social mental form (just like science, myth, religion or ideology), distinguished by its development methods and the nature of societies within which it acts, observes and rules. In short, in any case, the nature of modern societies confers a very distinct status of representation. Therefore, it is exactly this same modernism, or at least a hegemonic form of the latter, that often imprisons and poisons the diversity of thinking processes. It is an illusion offered by our modernism to think of a person as a rational being in a society ruled by science. Here we have one of the psychological tasks of social representations: to reconsider diversity of these anonymous heroes, beliefs, ideas and interactions, "the murmur of societies" (De Certeau, Jameson, Lovitt, 1980).

\section{A NEW HYPOTHESIS FOR ANCHORING}

The anchoring process is as ancient as the theory of social representations itself. It has been part of the theory from the onset of its initial formulation as one of the two main

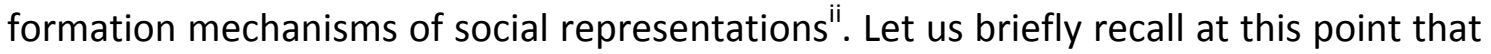
anchoring serves to weave parental relations between the newly issued significances of the social sphere and the reservoir of already existing knowledge that is culturally available and accessible. Through anchoring knowledge is constantly updated, enabling humans to cope with the uncertain features of new knowledge (information, image, event, notion, theory, person, group etc.), to face the unknown that represents novelty and to reduce the vacuum (emptiness) of comprehension and communication regarding this novelty. Speaking metaphorically, anchoring quenches the thirst for familiarisation with the un-familiar. In other words, thanks to anchoring, representation enters into the social, becomes "familiar" for the group while remaining tributary to systems of former categorizations, existing significance networks (cf. Viaud, 2000).

This "déjà-là", the knowledge system, in turn influences the destiny and degree of the gradual integration of the new by giving it priority (time), value (assessment), hierarchy (classification), a name (denomination). Thanks to its alliance, the relationships within this imaginable and functional network make anchoring representable: the social object and its different interpretations circulate within social groups. Familiarizing oneself with an object, an idea or person confers meaning and existence to that object. In contrast, a non-classified and un-named thing is uncommon, does not exist for the knower, and at the same time is threatening. 
In reminding these key notions of La Psychanalyse, we hope to focus on pre-existing thought processes involved in anchoring, as the platforms of social transmission by excellence. They forge, dictate and anticipate reality and so they renew it. They are largely instrumental in the constitution and expression of social relations. Two contradicting visions of anchoring could be discerned:

A conservative vision of anchoring entails its reduction to a simple normative metasystem. In accordance with this vision, the new object simply inherits characteristics of a normative category that confers a soft and consensual feeling. It therefore becomes, despite its novelty, an element among others; it is certainly a new element but it preserves the larger portion of the category's basic organizational principles. For example, a mechanical incorporation, the dynamics of change directed within, and a passive transmission are examples of such characteristics of conservative vision.

An idealistic vision of anchoring can be thought about as a pacifying mechanism, a reservoir of previous knowledge into which a new functional element is introduced and propagated. This confers its novelty to the previous knowledge, partially transforms the original category and works, on a long term basis, towards an active transformation or change.

Two different visions, one static and the other dynamic, have one point in common: they both have strategies for incorporating the new. The question remains, though, how to explain the persistence of a certain number of "impossible" familiarisations, namely those that involve alterity ${ }^{\mathrm{iii}}$ in all their forms, or the transmission of historically delicate periods? (Haas, 2002).

One of the main functions assigned to anchoring is to domesticate the uncommon. This presupposes openness to the new and unfamiliar, or we could say, a certain sense of hospitality. Let us continue, for a moment, with this metaphor. The hospitality laws established in Athens and Rome imposed the law of welcoming the stranger. They even promoted the exchange of half a symbol that took the shape of an object (for example a fish), which also created a link to the debt. However, at no time did the hospitality laws signify the acceptance of the uncommon under any other status than under the uncommon. Incorporation of novelty and familiarisation with the uncommon was acceptable but the novelty maintained the uncommon status. An opposite procedure, though somewhat symmetrical that led towards exclusion, was ostracism. Once again, an object (a shell or a piece of pottery) served to enter the name of the one that the community collectively decided to ban and exclude, without the possibility to reclaim its status. Disaffiliation of the familiar or de-familiarisation served the purpose of resetting and protecting the initial category.

We shall now propose a hypothesis that will suggest that traditional familiarisation allocated to anchoring can also work in the opposite sense, i.e. guaranteeing the nonfamiliar and ascertaining that the non-familiar remains strange.

Let us look at a classic example from the study by Jodelet (1992) on mental illness. In her monograph, the author showed the permanence and reinforcement of the archaic belief that insanity was contagious within a community that had the distinct experience of living with the mentally ill. This belief, that filled functions of the symbolic protection and defence of a community against a "threatening" alterity, was reactivated because - or despite of - the introduction of medications. Jodelet (1988, p. 
403) wrote: "Everything happened as if there was a storage in social memory of an interpretation of reality that we do not eliminate entirely, just in case it should happen that we would need information that rendered it useful. A type of guarantee against the unknown of the future". Here is an illustration of familiarisation working in the opposite sense, a familiarisation with the strangeness of mental illness that, furthermore, resists the new that could validate it. Here, the transmission takes on the role of protection.

Let us pause for a moment on another classic example, borrowed from phenomenology, namely two articles by Alfred Schütz $(1944,1945)$ with a specific psychosocial interest (the first of them has even been subtitled "An Essay in Social Psychology"). In these two papers, The Stranger and The Homecomer, the author questions the problem of familiarisation facing people who leave their usual collective setting, visit another setting, belong to it and live there as a member of the cultural group (multiplicity of intra- differences) and then return to the country of their origin. Both texts are characterized by a common aporia, that of a delicate, almost impossible familiarisation, because - or despite of - the domestication of these initial categories. A close-knit group, but a different one, is no more familiar than a primary group after a long absence.

Thus we propound that the difference, notably that of alterity, in scientific or social thinking, is not always compatible with "positive" familiarisation. This hypothesis, initially maintained by a study published recently (Kalampalikis, 2007), has become even more plausible due to other kinds of evidence (cf. Moscovici, 2002; Kalampalikis, Daumerie, Jodelet, 2007; Rose, 1998).

The research by Kalampalikis (2007) involves the study of antagonism between two national groups, one in Greece and the other in the Republic of Macedonia. Antagonism arises because of a name. A symbolic conflict surrounds a denomination. The real bone of contention represents the major identity challenges for each of the two vital and incompatible groups. We have ascertained the difficulty in naming, thinking, perceiving and classifying, briefly, in representing oneself by a name-label that the group has decided to allocate to it. These qualifiers were conceived and used solely by, and for, the national group following an identity strategy. The purpose of name-label was to make the "other" different, or one might even say, strange or uncommon. The only socio-cognitive familiarisation setting that has been activated during this process for young Greeks was no other than the one from its past ("Yougoslaves"), a general category that guarantees difference by neutralizing all fears of danger.

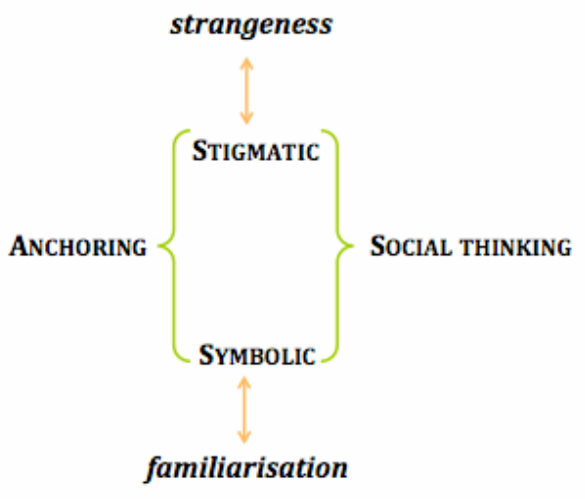


Using the distinction recently proposed by Moscovici (2002) between stigmatic and symbolic thinking, we can conceive of this in a somewhat similar manner as anchoring (Figure 1). The first form of anchoring is compatible with symbolic thinking introducing familiarity, and the second form of anchoring is compatible with stigmatic thinking introducing strangeness. Thus, in the perspective of social transmission we can conceive of a new form of familiarisation, that is, familiarisation with the uncommon, the non familiar, the strange, the not me, that guarantees, orchestrates or institutes a difference.

Social representations as the forms of worldly experiences are alive and dynamic. The exceptional longevity of the theory has been also evidenced in other social sciences, e.g. in sociology and anthropology (cf. Alexander, 2007; Becker, 2007; Godelier, $2004^{\mathrm{iv}}$ ).

These two temporal phases have brought us, each in our own manner, to revisit the epistemological kinship between a collective psychology project, the concept of cognitive polyphasia and even the paradoxical forms of familiarisation. This is of course an unending undertaking in terms of open paths of reflection. But we could arrive at a conclusion that social representations are always something in addition to what we are studying, just as the symbol is always more than what it symbolizes. More than a theory, a symbol of social thought.

\footnotetext{
* Assistant professors in social psychology, University of Lyon, Institute of Psychology, Research Group on Social Psychology (GRePS - EA 4163, PSeCO), 5 avenue P. Mendès-France, 69676 Bron cedex (France). contact : nikos.kalampalikis@,univ-lyon2.fr, valerie.haas@univ-lyon2.fr NOTES

i We know today, in particular in the light of the notes resulting from Durkheim's courses of philosophy to the Lycée de Sens, that the very idea of collective representations was in germ in its thought since 1883-1884 (Schmaus, 2004).

ii Willem DoISE (1992-3) has differentiated three types of anchoring (psychological, psycho-sociological, sociological) as organizers of symbolic relationships based on our social positions and memberships. There is no point in reviewing or proposing an additional type of anchoring.

iii Can we not speak of alterity, "complete" social representations ("représentations sociales totales") using the vocabulary of Marcel Mauss (1950)?

${ }^{\text {iv }}$ Let us signal, regarding this subject, one of the last editorial projects by Pierre BouRDIEU, illustrated by handwritten notes, devoted to the question "How do we represent the social world to ourselves?" (Actes de la Recherche en Sciences Sociales, 2004).
}

\section{BIBLIOGRAPHY}

ACTES DE LA RECHERCHE EN SCIENCES SOCIALES. (2004). Comment se représente-t-on le monde social ?, 154(4), 3-9.

ALEXANDER, J. (2007). Performance et pouvoir. In M. Wieviorka (Ed.), Les sciences sociales en mutation. Paris: Editions Sciences humaines, pp. 301-310.

BECKER, H. (2007). Telling about society. Chicago: University of Chicago Press. 
BRUNER, J. (1996). Meyerson aujourd'hui : quelques réflexions sur la psychologie culturelle. In F. Parot (ed.), Pour une psychologie historique. Ecrits en hommage à Ignace Meyerson. Paris: PUF, pp. 193-207.

DE CERTEAU, M., JAMESON F., LOVITT, C. (1980). On the oppositional practices of everyday life, Social Text, 3, 3-43.

DOISE, W. (1992-3). L'ancrage dans les études sur les représentations sociales, Bulletin de Psychologie, 405, 189195.

DURKHEIM, E. (1898/1974). Représentations individuelles et représentations collectives, Revue de Métaphysique et de Morale, VI : 273-302. In E. Durkheim, Sociology and Philosophy. New York: The New Press.

DUVEEN, G. (2000). The power of ideas. In S. Moscovici, Social representations. Explorations in social psychology. Cambridge: Polity Press.

FOURNIER, M. (2007). Emile Durkheim (1858-1917). Paris: Fayard.

GODELIER, M. (2004). Métamorphoses de la parenté. Paris: Fayard.

HAAS, V. (2002). La face cachée d'une ville. In T. Ferenczi (ed.), Devoir de mémoire, droit à l'oubli ?, Paris: Editions Complexe, pp. 59-71.

HAAS, V. (ed.) (2006). Les savoirs du quotidien. Transmissions, Appropriations, Représentations. Rennes: PUR. HALBWACHS, M. (1925/1994). Les cadres sociaux de la mémoire. Paris: Albin Michel.

HALBWACHS, M. (1938). La psychologie collective du raisonnement, Zeitschrift für Sozialforschung, 357-374.

HALBWACHS, M. (1999). Ma campagne au Collège de France, Revue d'Histoire des Sciences Humaines, 1, 189228.

JODELET D. (1988). Pensée sociale et historicité, Technologies, Idéologies, Pratiques, VIII(1), 395-405.

JODELET, D. (1992). Madness and Social Representations. Hemel Hempstead: Harvester.

JOVCHELOVITCH, S. (2006). Knowledge in Context. Representations, Community and Culture. London: Routledge.

KALAMPALIKIS N., DAUMERIE N., JODELET D. (2007). De l'effet médiatique au fait politique: la santé mentale en question, Information Psychiatrique, 83(10), 839-843.

KALAMPALIKIS N. \& MOSCOVICI S. (2005). Une approche pragmatique de l'analyse Alceste. Cahiers Internationaux de Psychologie Sociale, 66, 15-24.

KALAMPALIKIS, N. (2007). Les Grecs et le mythe d'Alexandre. Étude psychosociale d'un conflit symbolique à propos de la Macédoine. Paris: L’Harmattan.

KARSENTI, B. (1995). De Durkheim à Mauss: la spécificité psychologique de la sociologie. In M. Borlandi and L. Mucchielli (eds), La sociologie et sa méthode. Les Règles de Durkheim un siècle après. Paris: L'Harmattan, pp. 297-319.

KUHN, T. (1970). Logic of Discovery or Psychology of Research ?, In I. Lakatos and A. Musgrave (eds), Criticism and the Growth of Knowledge. Cambridge: Cambridge University Press, pp. 1-20.

LEVI-STRAUSS, C. (1947/1967). Les structures élémentaires de la parenté. Paris: Mouton.

LEVY-BRUHL, L. (1949). Les carnets de Lévy-Bruhl. Paris: PUF.

MARKOVA, I. (2003). Dialogicality and Social Representations. Cambridge: Cambridge University Press.

MAUSS, M. (1950/1997). Sociologie et anthropologie. Paris: PUF.

MOSCOVICI, S. (1961). La psychanalyse, son image et son public. Paris: PUF.

MOSCOVICI, S. (2000). Social representations. Explorations in social psychology. Cambridge: Polity Press.

MOSCOVICI, S. (2002). Pensée stigmatique et pensée symbolique : deux formes élémentaires de la pensée sociale. In C. Garnier (ed.), Les formes de la pensée sociale. Paris: PUF.

PAROT, F. (2000). Psychology in the Human Sciences in France, 1920-1940: Ignace Meyerson's Historical Psychology, History of Psychology, 3(2), 104-121.

PIAGET, J. (1926/2003). La représentation du monde chez l'enfant. Paris: PUF.

REVEL, J. (1996). Psychologie historique et histoire des mentalités. In F. Parot (ed.), Pour une psychologie historique. Ecrits en hommage à Ignace Meyerson. Paris: PUF, pp. 209-227.

ROSE, D. (1998). Television, madness and community care, Journal of Community \& Applied Social Psychology, $8(3), 213-228$.

SCHMAUS, W. (2004). Rethinking Durkheim and His Tradition. Cambridge: Cambridge University Press.

SCHÜTZ, A. (1944). The Stranger: An Essay in Social Psychology, The American Journal of Sociology, 49(6), 499507.

SCHUTZ, A. (1945). The Homecomer, The American Journal of Sociology, 50(5), 369-376.

VIAUD, J. (2000). L'objectivation et la question de l'ancrage dans les représentations sociales. In N. Roussiau (ed.), Psychologie sociale. Paris: InPress, pp. 89-100.

WAGNER, W. \& HAYES, N. (2005). Everyday discourse and common sense. Hampshire: Palgrave Macmillan. 